\title{
2
}

\section{Public Intimacy and 'White Feminism': On the Vain Trust in Scandinavian Equality}

\author{
Mikela Lundahl Hero
}

One issue that is of major concern to us and that we have begun to publicly address is racism in the white women's movement. As Black feminists we are made constantly and painfully aware of how little effort white women have made to understand and combat their racism, which requires among other things that they have a more than superficial comprehension of race, color, and Black history and culture. Eliminating racism in the white women's movement is by definition work for white women to do, but we will continue to speak to and demand accountability on this issue.

The Combahee River Collective Statement

Combahee River Collective

M. Lundahl Hero $(\bowtie)$

School of Global Studies, University of Gothenburg, Gothenburg, Sweden e-mail: mikela.lundahl@globalstudies.gu.se 


\subsection{What Happened in Sweden?}

For a long time Sweden was seen both by others and by itself as an exemplar and an exception when it comes to all kinds of equality (Bengtsson 2019; Habel 2012). But lately both the far right and many on the left have articulated scepticism regarding the success of that paradigm. Most infamous is perhaps the American President Donald Trump who seemed to relish highlighting the presumed failure of Swedish migration politics (Noack 2017). ${ }^{1}$

Lately, something called 'white feminism' has been articulated in social media, especially by women of colour, who use it to articulate the lack of solidarity and understanding of white privilege in the hegemonic feminist discourse. As someone who is literally a white feminist and who wants to be able to continue being a feminist while white, I have become increasingly interested in how feminism and equality is evoked in different contexts in ways that seem to make it possible to articulate racism without referencing race or bodies, but rather behaviour and values. In a number of recent events/debates in Swedish public life-either directly or indirectly through the usage of gender discourse-actors not usually associated with feminism have made statements about Sweden and Swedishness. In this chapter I will critically examine some samples of this mainstream feminism discourse - or equality politics—with the help of concepts like femo- and homonationalism, secularism and decoloniality (Connolly 1999; Farris 2012; Puar 2007). My point of departure will be some of these conflicts, which-in relation to their actual relevance for real people-have taken up a disproportionately large space in Swedish public life, which concerns Muslim individuals who have tried to participate in public life in Sweden. The conflicts concern two issues: one involves women who want to use public swimming pools in a way that works with respect given to modesty and in relation to Muslim beliefs of gender separation; the other concerns a politician who had to step down after avoiding shaking the hand of a female journalist, since he viewed this as contrary to his religious beliefs.

Both of these conflicts attracted considerable media controversy, and concepts such as 'feminism' and 'equality' were referenced in these debates 
and in the interventions that took place both in social media and traditional media. Even if there is a gap between the debates and reality, the debates are part of changing the discourse about Swedishness, democracy, gender and equality; I argue that they have political consequences and are therefore important to analyse. To contextualise these Swedish debates, I will reference recent research and similar events in other northern and western European settings, such as Denmark, Netherlands, Belgium, France, Austria and Italy, among others (Brems et al. 2018; Farris 2012, 2017).

\subsection{Feminist Challenges of the Future}

Apart from being threatened by anti-genderism, which will not be further addressed here, feminism is being challenged from a place that appropriates feminist discourses and can therefore be mistaken for feminism. This needs to be taken seriously. The fact that both women's and LBTQI rights have, to some extent, become policy and part of a common discourse is a real victory, but like most victories it has come at a cost and has not solved all problems. In order to secure its impact, feminism-or some versions of it at least-has adapted to current neoliberal and individualistic power structures, thereby losing a lot of its radicalism. In her provocative book Why I am not a feminist Jessa Crispin argues that feminism has been part of shifting the 'focus from society to the individual', and she regrets that

[w] hat was once collective action and a shared vision for how women might work and live in the world has become identity politics, a focus on individual history and achievement, and an unwillingness to share space with people with different opinions, worldviews, and histories. It has separated us out into smaller and smaller groups until we are left all by ourselves, with our concern and our energy directed inward instead of outward. (2017: 9)

The hegemonic feminism has limited its scope to gender, and omitted the intersectional analysis that highlights how interwoven gender oppression 
is with other forms of oppression, such as class, race, ethnicity, health, religion and sexuality (Crenshaw 1991). Moreover, the feminist struggle has become an individual matter rather than a collective one, which fits nicely into the neoliberal paradigm and ignores women who do not fit into the everyday understanding of the term 'woman' (white, middleclass, cis, secular, straight, healthy, etc.). However, intersectionality does not solve everything and, as Leticia Sabsay argues, there is a tendency for intersectionality to contribute 'to the creation of reactionary figures such as the (presumptive heterosexual) "oppressed Muslim woman"' when it 'should offer us a way to analyse how, for instance, islamophobic arguments serve the defence of feminist emancipation discourses, or how new homonormativities are functional to nationalist ideals and therefore complicit with contemporary forms of cultural racism' (2012: 613). Moreover, many contemporary intersectional practices seem limited to elaborating on only one other intersection at a time. Brown women are assumed to be cis and hetero whereas *trans* and queers are assumed to be white and middle class, or, in the words of Jasbir Puar, 'the homosexual other is white, the racial other is straight' (Puar 2007: 32; Sabsay 2012).

Feminists and others have, for a long time, noted that despite major progress and some important victories having been won observed that not everything is perfect in Scandinavia (compare the unfortunate tendency to use Sweden as a brilliant example in, for instance, SIGNS (Enloe et al. 2018)). Even if the idea of Sweden as a radical and equal space, a vision shared by foreign scholars and mainstream debaters, is true, to some extent, that narrative hides how biased and conditioned that equality is in reality. In fact, I believe that the image of Sweden as a place where we have 'arrived' in the future is a dangerous one, firstly because it is false and secondly because it strengthens the already dominant liberal idea of one universal form that the desired society could take, and the path towards it. Saba Mahmood argues that

[f] eminism, therefore, offers both a diagnosis of women's status across cultures as well as a prescription for changing the situation of women who are understood to be marginal, subordinate, and oppressed (2001: 206f). 
There are many aspects of the feminist agenda that are not fully articulated, that are silently or unconsciously universalised, and this is something that needs further investigation (Mahmood 2001: 206).

\subsection{Delicate Intimacy}

Intimate activities that involve care of the body, as well as dressing and undressing, are almost always and everywhere a delicate matter. They tend to be surrounded by rules and rituals that control who can see and touch whom and what (Foucault 1990, 1992). Sports and bathing customs are included in this affective and troublesome area of being human, and sometimes they contradict or disturb the normalised order, as the case of the infamous burkinigate in France showed not so long ago (see Almeida 2018; Berg and Lundahl 2016).

There are different kinds of arguments against veiling practices. For example, in France it was argued that people wearing burkinis were a threat, seen both as potential terrorists and as moral offenders (Berg and Lundahl 2016). In Sweden, by contrast, the arguments are often framed more along the lines that Swedish society and its institutions should protect veiled girls and women from patriarchal cultures - in the latter case, veiled individuals are obviously being stripped of their agency, without even making any observation of exactly how simplistic the understanding of agency often is within a western secular context (Mahmood 2001: 203f).

At first glance, there seems to be a broad consensus on the need to enable Muslim women, and particularly Muslim girls especially, to participate in public life, including sports and swimming. On the other hand, they can be met with rejection when they demand adaptations in order to accommodate their needs — as was the case for the Swedish girl who couldn't participate in the national basketball league because she wanted to play in a headscarf. This is part of an aporic situation, in which it appears that the liberal democratic state is both urging girls to participate in physical activities, but simultaneously reluctant to let them do so in a manner that suits them and their families (Brenning 2016). These restrictions are made in the name of the freed and emancipated girl/ woman and in the case of the basketball player there was a reference to 
safety, as if the veil can only come in the form of a burqa - a suggestion that shows a total lack of awareness of the modern sports hijabs that are available almost everywhere.

In one study in another Western European country Brems et al. interviewed women in Belgium with regard to their swimming practices and concluded that they wanted to 'combine a religious lifestyle with an active lifestyle, including sportive swimming and beach holidays' (2018: 10). ${ }^{2}$ This conclusion shows how religiosity is assumed to be connected to some specific values and incompatible with others. They have to be explicit in how they want to be not only religious, but also active and modern. In their preface to Is critique secular? Wendy Brown, Judith Butler and Saba Mahmood argue that secularism is held in place by other core values such as reason and critique:

not that secularism is wrong, but rather that secularism is inherently generative and suffused with religious content, that reason always tenders a particular order of rationality, and that critique is inherently situated and partial. We thus aim to undo the ways that secularism, reason, and critique stipulate and secure one another in contemporary Western discourse. (Brown et al. 2013: xix, my emphasis)

This idea of securing sheds light on the affective power that affects the societal response to different kind of veilings, or indeed other practices understood as religiously motivated. As we shall see later, there are sometimes similar practices, not associated with religion, that are met very differently, or even go unnoticed.

Just as secularism is associated with certain values, religiosity is associated with others, often the opposite ones. Secularism is associated with freedom and activity; religiosity with passivity and a lack of freedom, as well as being grounded in belief rather than in reason and critique. According to the women in the Belgian study it is impossible to imagine a situation where women who show signs of religiosity also embody agency and desire an active lifestyle.

Yet these women are living the contradiction: they demand both a 'modern' active lifestyle, while dressing according to their religious values. One should be able to read veiling through this example rather than 
through the lens that cannot see anything other than passive victims. These are women with agency, who challenge the strong secular norms in most European countries. Many Muslim European women who choose to veil are showing a lot of bravery, first when they choose to veil in an Islamophobic and veil-obsessed society as ours, and then when they insist on transgressing expectations on them when it comes to sports and swimming (and, although it is not relevant for this chapter, they carry this challenge into other areas of their lives, such as education and careers). These women thus challenge both the Muslim and the secular community. In the words of one of the interviewees in the article by Brems et al., it is a matter of 'agency about your own body and deciding yourself which part to show' (2018: 10).

The banning of burkinis or other hindrances to accommodating the needs for women and girls to achieve an active lifestyle (Berg and Lundahl 2016) enforce the boundary between secular and religious lifestyles and strengthen the associations of religiosity (not that veiling or modesty belong exclusively to the religious sphere) with passivity and backwardness, and hinder modernity to develop in diversity and including many experiences and expectations (Fabian 2002 (1983); Koselleck 2004).

Another finding from the Belgian study was the concurrent reference to 'neutrality' - it is often argued by the attendants at Belgian public swimming pools, who were interviewed by Brems et al., that burkinis are not allowed because:

the swimming pool is neutral, and that there is no place for religion in the water. (Brems et al. 2018: 11)

It is commonly argued that secularity is neutral, a sign of freedom, reason, universality and unmarked, whereas the religious is seen as culturally situated, unfree, deterministic, irrational, particular and primitive (Berg et al. 2016; Lundahl 2017). We found in an earlier study that, when a shopping centre in Sweden had let pupils from a nearby school illustrate a wall with people from the neighbourhood, just before the holiday season of 2015, which included a veiled woman which was subsequently erased, the arguments for erasing the veiled woman, were neutrality and 
secularity - with 'Ave Maria' playing on the sound system (Berg et al. 2016). According to Brems et al.'s material:

is actually often about women [...] who are somewhat more open-minded, often somewhat higher educated and who mainly actually will decide themselves what they consider the essence of their belief, and what they consider true and what they consider not true. (2018: 13)

This is a group of women who are silenced through the conceptualisation of 'Muslim women' or veiled women, just as Gayatri Spivak (1988a) and Chandra Mohanty (2003) have argued when it comes to similar tropes, such as 'third world women' - that hide the huge diversity within that 'group' when it comes to class, education and living conditions. The women interviewed in the Belgian study do not support the idea that all veiled women are oppressed:

It is not about people who blindly follow certain religious leaders, but about people who really have their own idea about how they want to experience their religion and they actually try to integrate all aspects of their lives as well as possible. So, they want to participate actively in society; they are usually people who work, who are also active in the community, and who also want to participate in sports activities, and who then actually go looking for clothes to actually integrate their religious conviction with their active lifestyle: how they want to stand in life and actively participate really in society. (Brems et al. 2018: 13)

The default banning that Brems et al. identify is excluding the most expansive and active part of the veiled group. Women who in their daily lives are actively bridging the gap between traditional and/or religious people, are forced to choose-there is no place in-between, where you can be both Muslim and modern, no borderlands (Anzaldúa 2012: 101). In practice, this has been part of western approaches towards Muslim women for decades (Lundahl 1995). The administrators at the public swimming pools are referring to something they label 'swimming culture', which in itself is an interesting oscillation between arguments. The first argument, articulated from a liberal democratic perspective and which refers to neutrality, seems to morph into an argument about 
Swedish, Belgian and European culture, or something which is labelled 'swimming culture'. The argument changes gradually from an idea of an imagined neutrality to one that merely expresses how we've always done it, which in itself is seen as a reason to finish off the discussion (Brems et al. 2018: 16). To end up in a culturalist argument is quite far from arguments of neutrality, and to make sense of that one has to remember that European culture is often equated with universal values.

\subsection{Appropriate and Inappropriate Clothing}

As we will see, the situation differs between Sweden and, for example, Belgium, since to date, the reality in Swedish institutions such as public swimming pools differs from the public debate. In Sweden, there is a gap between the practice at institutions (and their regulations) and the public debate. Time and political development will tell whether these debates will lead to institutional changes.

In their research, Brems et al. checked public swimming pools' regulations of how to dress inside the pool. From a similar brief search on public swimming pools in my own area, south-west Sweden, some of them in bigger cities, both central and in different suburbs (poor and rich) and some in smaller towns, ${ }^{3}$ I found that the rules were quite including, they were often explicitly mentioning the burkini or sometimes formulating the concept in words that related to the fabric of the clothes that were worn (Lycra). The most frequent and strongly stressed rule related to the issue of wearing underwear under your swimming clothes-an issue related primarily to a fashion among teenage boys and young men. More or less everything that is actual swimwear is allowed and it seems as even if in some cases the burkini is not mentioned specifically, it is still included in the overall term swimwear (badkläder). Or as it's stated under the headline 'trivselregler' (rules of comfort) at Gothenburg's biggest public swimming pools:

In all common space swimwear without underclothes should be worn. Male visitors should wear swim pants and female visitors should have a one or two piece swimsuit, or burkini. In the sauna and in showers, no swimwear should be used. (Valhalla) ${ }^{4}$ 
Through this phrasing the burkini is subtly transformed from something alien to one of the alternative female (one or two pieces, or burkinis) swimsuits. So, in that sense the text is quite inclusive. But it also reflects a 'swimming culture' that is rarely spoken of - that Sweden has genderseparated venues for changing and showering, where everyone is supposed to undress in front of each other. In combination these two facts, the gender separation and the nakedness, are taken for granted, but one does not need to travel far to see other solutions to the delicate intimacy of the nude body. This is not the case in all European countries-it might be a part of a 'Swedish swimming culture', which in Sweden is understood not so much as a culture but as a rational —or even universal—way to keep both humans and nature clean, that for example contains an ambition to minimise the usage of chlorine-a practice that differs from other parts of the world, hence the strong emphasis on nude showers before entering the pool and the usage of proper swimwear. This argument lines up fine with another (together with equality) brand of Sweden: maybe not so sophisticated but indeed clean and sustainable.

At the other public swimming pools I checked (Uddevalla; Angered; Askim), there were similar formulations, often without explicit reference to specific clothing, but still subtly inclusive. What came through is that the municipalities are explicitly open to all kinds of swimmers in all kind of swimwear as long as the swimwear is clean and made of Lycra. I found only one example of gender separation: in Angered one of their pools (or rather a pool system - a spa area) offers one evening for 'men only' and one for 'women only', weekly (Angered). But that might belong to another discourse, of girls'/boys' night out, treating themselves; that is, heterosexual gender binarism at its finest.

\subsection{The Dangerous Separation}

There have been demands for the introduction of girls-only hours at some public swimming pools around Sweden. Mostly, these demands have not been met, or have not been normalised. However, they have sparked debates on gender separation and the consequences of opening that door. 
In an op-ed piece, liberal debater Karin Rebas refers to women's movements' long struggle for equality:

For me it is simple. The Swedish equality is a result of many decades of conscious struggle. It builds upon the fact that men and women are regarded as equals and are mixed in public spaces: in workspaces, in schools, in hospitals and in public swimming pools. Those who prefer other norms and principles have to-with the words of Mustafa Panshiri-learn to handle it. (Rebas 2016)

The liberal rhetoric with regard to these subjects tends to begin with common sense arguments on which that we can all more or less agree, as the narrative of Swedish equality politics' long and proud history, where men and women are seen and treated as equal. Rebas then argues that with equality follows gender mixing. She argues in an insidious way that makes it sound as they must follow upon each other, in a way that relies on the securing mechanism that Brown et al. pointed out (2013). However, there are many examples of gender separation in Swedish society, not least when it comes to public swimming pools. One example is pointed out by Anna Ekelund Nachman who recalls from her own childhood how, in her local public swimming pool, in the south of Sweden, nude women exited the pools just before the third graders jumped in, and on other days it was nude men who enjoyed the swimming pools (Nachman 2016).

In fact, there are many different 'bathing cultures' existing side by side in Swedish society, and they all have their own logic. If we look at the traditional outdoor baths scattered along the Swedish coastline, dedicated to nude bathing, gender separation is a given. Women have their space and men theirs. Smaller facilities often have separated hours. For example, the new public sauna in the docks of Gothenburg (Frihamnen) has mixed, female-only, and male-only hours. ${ }^{5}$ These separations are rarely questioned by the liberals who express concern of an impending gender apartheid system, as they have no connection to religion, or anything that seems 'foreign'. They pass as neutral when in fact they're part of a tradition - or perhaps of a 'bathing culture' where gender separation is a given. ${ }^{6}$ Recently, however, they have been challenged by queer 
activists, who argue that they are too marked by binary gender thinking. This critique has sometimes been met with certain mixed or queer hours (Malmö; Frihamnen).

The former social democrat Ronja Ismail, who migrated from Iran to Sweden, situates the demands for separate hours in the public swimming pools in the Middle Ages, alluding in her argumentation to what Johannes Fabian has labelled denial of coevalness - that is, conceptualising the world in a way where different societies are placed in a development staircase, and understood as living in different historical epochs - thereby denying their coevalness (Fabian 2002 (1983)). Further, she argues that since we are not Iran or Saudi Arabia, it is therefore obvious that we cannot listen to the demands for women-only hours at public swimming pools:

Since if the municipal swimming pool give way to these medieval demands, what will be the next step? Is it uncomfortable to travel with women in public transport? Then voices will be raised for gender separated buses and trains. Should the daughter not go to school with boys? Voices will be raised for gender separated schools.

I already grew up in a country were gender apartheid became everyday life. When the islamistic mullas gained power in Iran everything changed in a day. Public spaces, as beaches, sports halls and swimming houses were the first to be gender separated. Soon girls and boys had to go to gender separated schools. To separate the genders in public transport, women were forced to sit back in the bus. The demands for gender separated swim hours in Nybro would be applauded by the Iranian ayatollah. (Ismail 2016)

Her chain of arguments ignores the long history of gender separation in Swedish institutions that coexist with spaces where no one would consider separation, which is seen as something completely different-but natural. When I went to school in the 1970s, for example, sports were often gender-separated. Ismail's usage of different timescapes situates other contemporary societies in an imagined past (Hemmings 2018). This line of argument fosters the assumption that development can only move in one direction-either forwards or backwards. There are no parallel routes; no diversity can be imagined. The idea of separate bath hours, which nobody is actually offering and few are requesting - apart from 
what has 'always' been there and is not included in these discussionswill necessarily take us 'back' to a fully gender separated society.

That's why I care about protecting the progress in the Swedish society. Here, I and many [...] women got to live a life in a freedom that we could only dream about in our home countries, countries where the societies are ruled by strong patriarchal norms and values.

But Sweden is neither Iran nor Saudi Arabia. And shall not become. Therefore it is obvious that our public swimming pools are open for women and men. [...] Anything else would be a betrayal to all of us who fled the religious oppression in the Middle East. (Ismail 2016)

Ismail's arguments are built up with the help of straw men and imagined terrible scenarios. One question that needs to be raised in relation to the last claim above is why Sweden should adapt to the specific experiences of those who fled the Iranian revolution. It was (and still is) an awful regime, but the politics of gender separation goes far beyond Iran and Saudi Arabia. Even if we recognise that the oppression by the Iranian regime, now and then, is a crime against humanity, especially against women, it is questionable to argue that Swedish politics with regard to veilings and gender separation should be formulated in such a way as to not 'betray' those who fled Iran, since the history and rationale behind people coming to Sweden is so diverse-even among those coming from 'the Middle East' — as is the rationale behind gender separation, which, as we've seen, is also common in Sweden. Her phrasing silences these women through the homogenisation of these diverse contexts to one and the same. Swedish politics need to accommodate many other stories and human experiences. Someone who was traumatised by the Iranian regime would perhaps make connections between incidents in our current society and past events; for everyone else, however, it is far-fetched to claim that Sweden is on the brink of becoming like Saudi Arabia due to some small changes in our public swimming pool regulations.

Ismail further states that 'Sweden should actually be equal and secular'. This quote is an exemplary articulation of what Brown et al. try to challenge, namely the idea that 'modern' values, such as equality, can only exist together with secularity. Further, she silences all other voices and the 
diversity among people in Sweden with an origin in the Middle East, including people who came from other parts of the Middle East, where the religious system looks different, or with other experiences, and for different reasons. In Ismail's narrative, Sweden is modern, and modernity is secular, and therefore cannot accommodate any kind of religionwhich we know it does, both in classic religious forms but also in alternative ways, as Bengt Kristensson Uggla (2015) and David Thurfell (2015) have shown. Ismail's arguments about religion-or Islam-draws exclusively on her experiences from Iran. I have no reason to question those experiences, but there are other experiences that we also need to accommodate in contemporary and future Europe.

Heidi Avellan from Sydsvenskan refers to Ismail and reveals her progressivist view on world history:

Happily enough the municipality did not back down, Ronja Ismail remarks, who grew up in Iran where gender apartheid quickly became normal when the mullahs came into power: beaches, sports facilities and public swimming pools, were the first to be targeted for gender separation. She is worried that voices also in Sweden can be raised for gender separated buses and a return to girls and boys schools. (Avellan 2016, my emphasis)

I am not arguing for separate schooling, but there is interesting research, practical experiences and good arguments for gender-separated schooling, or at least hours, in the name of equality. For example, in a muchreported incident in the 1990 s, some kindergartens in a small town close to Gävle in Sweden tried gender-separated activities in order to make children go beyond the expectations of their gender. This included, for example, encouraging girls to be bolder when it came to outdoor activities, or to stop helping out so much during lunchtime, where boys, on the contrary, had an opportunity to expand their capacity to articulate their needs, when there were no girls present, ready to interpret their needs. The rationale behind their practice was to compensate for the influence of 'gender ideology' on the young boys and girls, and give them opportunity to grow beyond the narrow boundaries of the two sexes (Blomquist 2008). Instead, many misunderstood the practice as being aimed at enforcing stereotypical gender models (Nilsson 2017). Are 
debaters making the same mistake when they can't see that separate bathing hours or special clothing might be what determines whether girls/ women from minorities can be integrated - a highly esteemed value by so many debaters-whereas if they cannot wear the veil, burkini or be in groups, they will be unable to participate at all? The notion that one has to appear the same to become one, seems to rule these liberal debaterswho usually make it their business to accuse the left and feminists of wanting to make everyone the same.

Lately, we have seen debates on how the current school system supports girls more than boys and how it has become a problem that boys don't seem to fit in in today's school systems, something that seems to be happening all over the world-often referred to as the 'girl effect'. That phrasing, however, might overshadow the negative consequences for boys and men, who lose not only in power but in knowledge and belonging in their societies (Kagaba 2016).

Why don't these liberal debaters simply come out and admit that they prefer one culture to another, or that they accept gender separation the Swedish way, but not the Muslim way? Why do they need to evoke feminism and equality? To not sound as racist and Islamophobic as they are? I believe that what we see from these debaters are efforts to try to address 'the problem with Islam' through the usage of gender equality, without sounding racist. A separatist strategy, in this discourse, can only be read as a return to something long overcome. They make it seem as if a strategy that has been used outside the liberal modernist hegemony will carry with it everything that might be problematic, as if it were contaminated by something not belonging to liberal modernist hegemony. But the liberal modernist hegemony can never be contagious in itself in that sense-since it is not understood as an illness, in the way that religion and some supposedly alien forms of patriarchy are.

However, if we were to scrutinise most of the common practices in the liberal modernist hegemony, most of them would probably be contagious and therefore disqualified, since they most likely have been used in misogynist, racist or homophobic contexts and are therefore not useful.

Heidi Avellan seems to recognise some of the challenges with her own position as a liberal, when she argues against freedom: 
Separate bath hours. Separate gym hours. Separate venues.

By choice and voluntary? Liberal then?

No, actually not.

[---]

It is simply about sticking to how it is. Like the fact that in Sweden, women and men swim together.

Arguments around the importance of exercise or swim training-and that it is therefore important to gender cleanse the pool-have to be set aside, as does the argument that this is somehow about religious freedom.

It is more important that women from patriarchal cultures are recognized as individuals, not as representatives of a medieval gender view. (Avellan 2016)

The way she uses the phrase 'patriarchal cultures' is illuminating - and here I will leave aside the complex concept of culture. She is constructing a patriarchal other, in contrast to an 'us' that is not? According to Joseph Massad, these ideals are part of the western imperialist impulse, which governs and secures who can define sexual freedom, equality, happiness, future, etc. (Massad 2008: 192f).

The war on veils and different body covering practices is spreading across Europe (see Brems et al. 2018). Denmark has recently introduced a new law that forbids garments that cover the face, including Islamic veils such as the niqab and burqa, although it's said to not aim at any specific religion and does not ban headscarves, turbans or the traditional Jewish kippa.

At the same time, however, veils are more debated than ever before, also in a more self-critical way, as in an article in the leftist daily newspaper Information, where Karen MacLean tries to make her own whiteness visible through exploring the privileges enjoyed by a body covered by a 'white niqab': 'I did not see that I myself is covered in a white niqab, that makes me deeply privileged' (MacLean 2018). She tries to articulate how white unveiled north European women such as herself live their livesunaware of the cultural niqab they carry around every single day in spite of their imagined freedom.

Recently, we have seen veils used in commercials (see Berg et al. 2016), as in the case of the Danish candy company Katjes, which featured a 
veiled woman in a very important ad campaign in central Copenhagen. The company leader explains that:

To us there is nothing political in using a model who wears a hijab. We are targeting the modern woman. The modern woman is diverse and future oriented, just as our products are, Dan Kongsted says. (Termansen 2018)

What is notable here is the fact that the featured veiled woman is saying yes to vegan candy, so the company is targeting several groups simultaneously, and establishes a bond between different groups that can be accommodated in a diverse and future-oriented community; groups that usually doesn't have a natural connection in Danish society - apart from saying no to pork, a staple in the Danish diet. ${ }^{7}$ Currently, the battle of the veil goes in several directions, and takes place in different arenas-and also apparently in commercials.

\subsection{Handshake Gate}

In the spring of 2016, a rejection of a handshake mobilised a storm of feme- and homonationalism, and new articulations of Swedishness were expressed publicly, with the Swedish prime minister Stefan Löfven leading the way: 'In Sweden we greet each other. We shake both women's and men's hands' (Löfven 2016). It was the Green Party member Yasri Khan, at the time a candidate for the Green party's board, who had politely refused to shake hands with a journalist. His stated reason was that shaking hands with a woman felt too intimate (Khan 2018).

One phrase that was used a lot during this 'gate' was 'the Muslim no handshake custom', which was presented as mandatory and widespread. This is a clear exaggeration. There are some branches of Islam where this is the practice of some of its members, but the formulation indicates that this is a common and dominant feature for all Muslims, which is not The case (L. Ahmed 1992).

This all happened in the spring of 2016, a little more than a year before the eruption of the \#metoo movement changed the conversation in Sweden. Before \#metoo it was suspicious to avoid handshaking with 
women-after \#metoo we've had to rethink body contact and realise that there is no neutral or unproblematic way to touch between the genders (I am painfully aware of the gender binarism and heteronorm in this discourse (see Clare Hemmings 2018: 971)), as was the Swedish 'go to' reflection. New norms and formulations are in the making as 'unwanted intimacy' which has become a notion, used by the late Sara Danius, former secretary of the Swedish Academy, in relation to what unfolded in that institution in the wake of \#metoo, and which describes the discomfort women feel when they have to accept cheek kisses-which is not a part of Swedish mainstream culture - or too long or close hugs-which are more mainstream nowadays - from men who stretch the limits and hide behind social norms to touch women. This has now become articulated and given a name and therefore something we talk about. \#Metoo has shown that the unity shown by Swedish society on a shared greeting system in the handshake gate is partly a myth and a silencing of the history of patriarchal norms that grant men access to women's bodies in public in ways that not everybody actually consents to.

In a related case, the refusing handshaker was a young Muslim woman who had avoided shaking hands with a male colleague, and who chose to quit her job after the incident. The principal at the school where she worked was eager to stress that this had nothing to do with her being a Muslim, but rather about equality:

I would like to clarify that the school did not sack Fardous. She chose to leave after I explained what the school's core values are. I would also like to carefully point out that the issue was not her religious beliefs, but rather it is about choosing to treat men and women differently by shaking the hands of women but not men. [...] We at the school treat all sexes on the principle of gender equality. If the the [sic] Equality Ombudsman were to decide that we have acted wrongly, we would naturally look at how we approach or interpret that. (Roden 2016)

Greetings become symbols that in the name of equality becomes battlefields, where, following the 'rules' without grounding them in judgement, seem to be the more important, than thinking through consequences and meaning. Sara Ahmed has argued that in the neoliberal state is put a 
lot of effort on the formulation and introduction of policies, whereas the actual realisation of them in a just practice, is not as emphasised, and this makes people follow the policy without reflecting on the reasons behind it (S. Ahmed 2004). It is hardly meaningful to accuse this specific teacher of implicit racism, based on the above statement. But I do believe that we shouldn't ignore the fact that these arguments, used in situations like the above, have excluding effects that target Muslims, and if we link that to the fact that we, for some time now, have seen a growing Islamophobia throughout the western world, we have to acknowledge the problem. As Leticia Sabsay argues:

The mobilisation of orientalist views on the other's supposedly backward gender culture has been prominent within the hijab debate in France and Spain for years. (Sabsay 2012: 607)

She further argues that 'all these tendencies attest to the racialisation of progressive sexual politics and its functionality in the process of cultural othering'. Progress is white and western and the other is 'sexually conservative, intolerant and [has] constitutively anti-democratic sexual values' (Sabsay 2012: 607).

What do we do with the contradictory notions of the classic orientalist imagery of the Muslim man as a perpetrator, who oppresses women, and on the other hand the effeminate (insufficiently masculine, according to Swedish standards) pious Muslim man? How can they live side by side in our contemporary modernity? Can the Muslim man speak? Beyond our notions or assumptions of who they are and what they believe. It seems as if 'the Muslim man', just as the subaltern brown woman Gayatri Spivak once wrote in a famous article, is over-determined and everything he says will either not be heard or will be interpreted according to the already created discourse about him (Spivak 1988a). Spivak's question 'Can the subaltern speak?' highlights the impossibility for Yasri Khan to actually be heard-whatever he says is channelled through our fixed mindset regarding Muslim men. We have several recent cases when the other actually turned out to be different, not only when it comes to skin colour or name, but in their views on politics and behaviour. 
Spivak's article is quite relevant within this context since we have seen a growing desire for representation in the political sphere, but less real preparation to accept real otherness. How other can someone be while still being accepted in the mainstream of political discourse? The acceptance has its clear-cut limitations.

Handshake gate concerns the integration and political representation of Muslims in western democracies, and is an opportunity to discuss the construction of masculinities, as well as how feminism is invoked in different ways, from both 'sides'.

From a contemporary intersectional feminist perspective, Khan's feminist politics are quite heteronormative; just as the feminist politics of those criticising him. Whereas the contemporary intersectional feminism that could have made a point about this, stays rather silent-perhaps (speaking for myself here) since we worry about the racist, Islamophobic overtones in events like this. As if the modern were ever a pure essence, void of traditions, and that Islam is the first to bring tradition into modernity (cf. Latour 1993).

\subsection{Futures of Feminisms}

It might be that the term feminism has to go, or at least go to rest for a while, in order to undo these universalising tendencies that hide the diversity in women's lives and conditions. Or at least an unqualified feminism. It might be necessary to use different prefixes, such as postcolonial, decolonial, black, queer and intersectional before it, in order to call out the whiteness and liberalness and middle-classness etc. of the term 'feminism'. All in order to challenge and undo the universal feminism that is to troublesome according to Clare Hemmings:

One reason why I think it is so important to track the appeal of 'universal feminism' that sutures feminism and femininity in some instances of contemporary representation, then, is that the citation of gender inequality's temporality allows for a reinstantiation of gender difference, all the while appearing to challenge the limits such binarism represents. (Hemmings 2018: 973) 
The concept of feminism might be a lost cause, as Jessa Crispin argues, since we are many white feminists who do not agree upon the public representation of white feminism, 'Swedish feminism' or even just as feminism - the one and only. If feminism has become a floating signifier- that it can mean almost anything and be used by almost anyone, we need to work on more specific terms and continue, in the words of Leticia Sabsay words, to

question the colonial or orientalist over-determinations that confirm a hegemonic understanding of the kind of subjects who can make demands and the forms those demands can take. (Sabsay 2012: 619)

We are still too framed in a

narrative of progress that dismisses other sexual struggles and justifies both normalising and condescending or overtly discriminatory racist cultural assessments. (Sabsay 2012: 619)

This narrative needs to be disrupted:

This task demands that we question the universalising normative framework that forecloses what we can understand as political, and reminds us that the language of western sexual citizenship is by no means the only way of making sexual claims. This challenge implies keeping open the basic political issue of how bodies and their pleasures can and do become the locus of political practices of citizenship beyond liberal and orientalist presumptions. (Sabsay 2012: 619, my emphasis)

I wish to join forces with all critics of universalistic feminism-or of other universalisms for that matter. Even if that project has been ongoing for decades it still seems as if feminism and many who identify as feminists, still ignore that they are deeply embedded in western thought, and are reluctant to realise that they are rather local than universal-just as everybody else. That also goes for their knowledge, and their solutions, which are developed in, and adapted to, local situations. The concept of local knowledge (Geertz 1983) is not only applicable to the third world 
and the other-it's the reality everywhere, even for the first, the privileged groups, such as white middle-class western feminists.

Feminism and/or feminists are seen, and identify, as radical and critical by default, but tend to be blind to the white mythologies framing their discourses and practices (Barthes 1957; Derrida and Moore 1974; Young 1990). One aspect of white feminist mythology is that everything that is different from it, is seen as belonging to a realm of tradition or culture in contrast to itself, which is understood as liberated and enlightened. This tendency to situate anything that oppresses women in temporal or spatial otherness is prevalent across the political spectrum. Inderpal Grewal describes this poignantly in her analysis of neoliberal consumer culture:

Although some of these cultural productions were not explicitly marked as 'feminist,' the discourses within these works were closely connected to liberal feminisms in which the movement from tradition to modernity signified a woman's move from repression and exploitation to freedom. Thus quite often it was not globalization or military repression or lack of resources or state policies that were used as an explanation for the continued subordination of women in the so-called third world, but rather the power of 'tradition'. (Grewal 2005: 65, my emphasis)

Western ideas are neither necessarily worse nor more problematic than any other cluster of ideas and practices per se. But it is their universalising tendencies and the silencing of their local nature-both in time and space - that is dangerous - even if they might also share that with other traditions. Those traditions, however, are not hegemonic on a global scale. Historical and geopolitical conditions have made it possible for those ideas to fly and be used with specific political ambitions disguised as neutral and global, in contrast to other ideas, which are declared to be foreign, other, traditional, cultural or local. It might be strategically necessary to separate the ideas from their effects in a specific geopolitical situation, so that those who are invested in the ideas can go on with them, but be open for a dismantling of them and end the universalising of them-if that is a possibility — or is the universalising a core value that liberal modernism cannot abandon?

One way of doing this is to scrutinise the saviour complex (Teju Cole, 'The White-Savior Industrial Complex', The Atlantic, March 21, 2012) 
which seems to be so strong in white feminism and as Gayatri Spivak argued long ago is more about the white feminists than about the 'saved' (Spivak 1988a, b). Or as Lila Abu-Lughod asks in her book Do Muslim women need saving? (Abu-Lughod 2013). Who are the Muslim woman that one wants to save, and why? And from what? There are millions of Muslim women, all living in very diverse conditions. The impecceble principles of many liberal white women will rarely help anyone in a real crisis.

It is urgent to question and destabilise notions of what a Muslim man and woman is or can be-as well as what white feminism is. Not because we are suffering, but because all work done in order to undo patriarchy, capitalism and white supremacy is needed. Regarding the latter, I believe that if we do not specify or situate the feminism we are using, we will see more pink washing, as 'gender awareness' - to some degree and in a certain form-grows. We need to call out the tendency to use 'feminism' or 'equality' in order to control femininity/masculinity, cis- and heteronormativity, whiteness or other nationalisms. In current times of migration and transnationalism, Sweden has to become more open-or as open as it imagines and represents itself to be. Our future imagined community cannot have only one accepted way to greet each other, or one way to organise bodies in sports and swim facilities.

White feminism and nationalistic gender equality exist in a temporality and an idea of the future where everybody should become more or less as the Swedish modern man and woman, and live as they are imagined to live in hegemonic narratives, and smaller anomalies can be accepted as same-sex couples as long as they follow the heterosexual manuscript/ matrix in every other way. Similarly, Muslims can be accepted if they do not ask for real changes to accommodate them as they are, rather than changing to what we want them to become, what we see as a good Muslim — that is, a secular, unveiled/shaved handshaking Muslim.

\subsection{The White Burden Revisited}

What are we supposed to do instead? The South African white activist Rick Turner argued in the 1960s and 1970s that we need to define a new whiteness (Turner 2015), one that listens to the other, but that doesn't try 
to erase differences. These differences might disappear or not, but it is not up to anyone to change anyone else (see Sartre 1989). Dare to own the white burden - that is the inherited white supremacy, coloniality, patriarchy and try to affect change from within. That is, a white feminism for the future that recognises itself, its privileges and power relations, taking responsibility for them, and acknowledging the white niqab, everything that we are unable to see or grasp, whichever intersections are applicable to our situation. Without a proper understanding of where we are, we have no clue on where to head next.

We ought to keep the wound of belonging to the oppressive line, and stay with the trouble (Haraway 2016). And keep cultivating the art of noticing outside the political and discursive ready-mades, and try to accept that:

the assumption that the trope of progress is sufficient to know the world, both in success and failure. The story of decline offers no leftovers, no excess, nothing that escapes progress. Progress still controls us even in tales of ruination. (Tsing 2015: 21)

\section{Notes}

1. By 'presumed' I am not arguing that Sweden has been very successful. Rather, what I'm questioning is the presumption that a successful migration politics could be possible in a neoliberal (or any kind of liberal) state.

2. In the referenced article the scholars interviewed staff at the public swimming pools whether they have a ban against burkini or not and why; they have interviewed burkini wearers, and they have looked at some actual juridical cases. It's worth noting that none of the referenced cases passed the juridical procedures. There were no arguments, regardless of whether they evoked gender equality, hygiene or safety, that held up in court (Brems et al. 2018: 17-18).

3. Göteborg Valhalla, Angered, Askim, Uddevalla, Malmö.

4. All translations from Swedish and Danish are mine.

5. At the time of writing the rules were updated to Transgender; She/Ze; He/ Ze and Mixed hours. 
6. It has, however, been questioned by queer and trans people, since those categories exclude non-binary people and have also been problematic for people with a body not aligned with their gender, when they have not been accepted on women's hour since their bodies are not seen as fully female. Femonationalism has become a part of the logic in these debates, but not, yet, homonationalism.

7. The ad was brought to my attention by a Danish veiling friend from a Middle Eastern 'background', who couldn't hide her joy when she shared this ad, put up in the same city which on a daily basis harasses her and questions her right to be there, in the country where she was born and of which she is a citizen. That joy tells us something about the current state of the Danish kingdom, in particular, and Euro-America in general.

\section{References}

Abu-Lughod, Lila. 2013. Do Muslim women need saving? Cambridge, MA: Harvard University Press.

Ahmed, Leila. 1992. Women and gender in Islam: Historical roots of a modern debate. London: Yale University Press.

Ahmed, Sara. 2004. The cultural politics of emotion. Edinburgh: Edinburgh University Press.

Almeida, Dimitri. 2018. Marianne at the beach: The French burkini controversy and the shifting meanings of republican secularism. Journal of Intercultural Studies 39 (1): 20-34.

Anzaldúa, Gloria. 2012. Borderlands: The new mestiza $=$ la Frontera. San Francisco: Aunt Lute Books.

Avellan, Heidi. 2016. Bada med grabbar. Också. Sydsvenska Dagbladet, 20160304. Barthes, Roland. 1957. Mythologies. Paris: Éditions du Seuil.

Bengtsson, Erik. 2019. The Swedish Sonderweg in question: Democratization and inequality in comparative perspective, c.1750-1920. Past \& Present 244 (1): 123-161.

Berg, Linda, and Mikela Lundahl. 2016. (Un-)veiling the West: Burkini-gate, Princess Hijab and dressing as struggle for postsecular integration. Culture Unbound: Journal of Current Cultural Research 8 (3): 263-283.

Berg, Linda, Mikela Lundahl, and Lena Martinsson. 2016. Sekulariteter-förstahet genom religion och kön. Kvinder, Kon \& Forskning 4: 7-19.

Blomquist, Lena. 2008. Lär barnen jämställdhet. Arbetet, 20080605. 
Brems, Eva, Saïla Ouald Chaib, and Katrijn Vanhees. 2018. 'Burkini' bans in Belgian municipal swimming pools: Banning as a default option. Netherlands Quarterly of Human Rights 36 (4): 270-289.

Brenning, Patrik. 2016. Får inte spela för att hon bär slöja. Aftonbladet, 20160929. Brown, Wendy, Judith Butler, and Saba Mahmood. 2013. Preface, 2013. In Is critique secular? Blasphemy, injury, and free speech, ed. Talal Asad et al. New York: Fordham University Press.

Connolly, William E. 1999. Why I am not a secularist. Minneapolis: University of Minnesota Press.

Crenshaw, Kimberlé. 1991. Mapping the margins: Intersectionality, identity politics and violence against women of color. Stanford Law Review 43: 1241-1301.

Crispin, Jessa. 2017. Why I am not a feminist: A feminist manifesto. Brooklyn: Melville House Publishing.

Derrida, Jacques, and F.C.T. Moore. 1974. White mythology: Metaphor in the text of philosophy. New Literary History 6 (1): 5-74.

Enloe, Cynthia, Agnieszka Graff, Ratna Kapur, and Suzanna Danuta Walters. 2018. Ask a feminist: Cynthia Enloe discusses gender and the rise of the global right with Agnieszka Graff, Ratna Kapur, and Suzanna Danuta Walters. Signs. Accessed 20200624. http://signsjournal.org/cynthia-enloe/

Fabian, Johannes. 2002 (1983). Time and the other: How anthropology makes its object. New York: Columbia University Press.

Farris, Sara R. 2012. Femonationalism and the 'regular' army of labor called migrant women. History of the Present 2 (2): 184-199.

- 2017. In the name of women's rights: The rise of femonationalism. Durham: Duke University Press.

Foucault, Michel. 1990. The history of sexuality Vol. 3 the care of the self. Harmondsworth: Penguin.

- 1992. The history of sexuality Vol. 2 the use of pleasure. Harmondsworth: Penguin.

Geertz, Clifford. 1983. Local knowledge: Further essays in interpretive anthropology. New York: Basic Books.

Grewal, Inderpal. 2005. Transnational America: Feminisms, diasporas, neoliberalisms. Durham: Duke University Press.

Habel, Ylva. 2012. Challenging Swedish exceptionalism? Teaching while black. In Education in the black diaspora: Perspectives, challenges, and prospects, ed. Kassie Freeman and Ethan Johnson. London: Routledge. 
Haraway, Donna Jeanne. 2016. Staying with the trouble: Making kin in the Chthulucene. Durham/London: Duke University Press.

Hemmings, Clare. 2018. Resisting popular feminisms: Gender, sexuality and the lure of the modern. Gender, Place and Culture 25: 1-15.

Ismail, Ronja. 2016. Säg nej till separata badtider. Barometern 20160302.

Kagaba, Mediatrice M. 2016. Understanding gender equality in Rwanda: The experiences of people living in rural communities. Göteborg: University of Gothenburg.

Khan, Yasri. 2018. Politician quits after refusing to shake women's hands. The Local se, 20160420.

Koselleck, Reinhart. 2004. Futures past: On the semantics of historical time. New York: Columbia University Press.

Kristensson Uggla, Bengt. 2015. Katedralens hemlighet: Sekularisering och religiös övertygelse. Skellefteå: Artos \& Norma.

Latour, Bruno. 1993. We have never been modern. Cambridge, MA: Harvard University Press.

Löfven, Stefan. 2016. Löfven: 'Man ska ta både kvinnor och män i hand'. Svenska Dagbladet, 201600421.

Lundahl, Mikela. 1995. Vi beslöjade. Glänta 1-2: 17-23.

- 2017. Borde samtiden av-sekulariseras? In Samtider: Perspektiv på 2000-talets idéhistoria, ed. Anders Burman and Lena Lennerhed. Daidalos: Göteborg.

MacLean, Karen. 2018. Jeg så ikke, at jeg selv er svøbt i en hvid niqab, der gør mig dybt privilegeret. Information, 20180822.

Mahmood, Saba. 2001. Feminist theory, embodiment, and the docile agent: Some reflections on the Egyptian Islamic revival. Cultural Anthropology 16 (2): 202-236.

Massad, Joseph A. 2008. Desiring Arabs. Chicago: University of Chicago Press. Mohanty, Chandra Talpade. 2003. Feminism without borders: Decolonizing theory, practicing solidarity. Durham: Duke University Press.

Nachman, Anna Ekelund. 2016. Separerade bad en gammal svensk tradition. Dagens industri, 20160406.

Nilsson, Bengt. 2017. Björntomten och Tittmyran. Vart tog den kompensatoriska genuspedagogiken egentligen vägen? In Kunskap motstånd möjlighet: Humanistisk forskning $i$ dag, ed. Ulrika Serrander, Peder Thalén, and Per Vesterlund. Molin \& Sorgenfrei förlag: Stockholm.

Noack, Rick. 2017. Trump asked people to 'look at what's happening... in Sweden' earlier this year. Now, Sweden responds. Washington Post, 20170912. 
Puar, Jasbir K. 2007. Terrorist assemblages: Homonationalism in queer times. Durham: Duke University Press.

Rebas, Karin. 2016 På kommunala badhus i Sverige badar män och kvinnor ihop. Kristianstadsbladet, 20180317.

Roden, Lee. 2016. Handshaking row causes Swedish teacher to leave job. The Local se, 20160922.

Sabsay, Leticia. 2012. The emergence of the other sexual citizen: Orientalism and the modernisation of sexuality. Citizenship Studies 16 (5-6): 605-623.

Sartre, Jean-Paul. 1989. No exit, and three other plays. New York: Vintage International.

Spivak, Gayatri Chakravorty. 1988a. Can the subaltern speak? In Marxism and the interpretation of culture: Communications and culture, ed. Cary Nelson and Lawrence Grossberg. Houndmills, Macmillan Education.

- 1988b. French feminism in an international frame. In In other worlds: Essays in cultural politics. New York: Routledge.

Termansen, Julie. 2018. Slik-gigant reklamerer med model i hijab: Vi henvender os til den moderne kvinde. Ekstrabladet, 20180810.

Thurfjell, David. 2015. Det gudlösa folket: De postkristna svenskarna och religionen. Stockholm: Molin \& Sorgenfrei.

Tsing, Anna Lowenhaupt. 2015. The mushroom at the end of the world: On the possibility of life in capitalist ruins. Princeton: Princeton University Press.

Turner, Richard. 2015. The eye of the needle: Towards participatory democracy in South Africa. London: Seagull Books.

Young, Robert. 1990. White mythologies: Writing history and the west. London: Routledge.

\section{Internet and Other Sources}

\section{Public Swimming Pools}

Angered. https://goteborg.se/wps/portal/enhetssida/angered-arena/bada/inforditt-besok/tvattadig/!ut/p/z1/04_Sj9CPykssy0xPLMnMz0vMAfljo8ziTYzc DQy9TAy93 c M s zA 0 cXYxd fM N cA 4 y 9 z Uz 0 w w k p i A K G AAjgb6BbmhigDBD40J/dz/d5/L2dBISEvZ0FBIS9nQSEh/30 nov 18.

Askim. https://goteborg.se/wps/portal/enhetssida/askims-simhall/bada/inforditt-besok/!ut/p/z1/04_Sj9CPykssy0xPLMnMz0vMAfIjo8ziTYzcDQy9 TAy93c2cnQ0cXT1NTV09DA3dQ031w8EKAgxdHA1NgAoMPAzdD BwDXc38g1xNDAx8TPWjiNFvgAIcDZyCjJyMDQzc_Y2I049HQRSG 
8cgW6RfkhoaGOioqAgAhbfyt/dz/d5/L2dBISEvZ0FBIS9nQSEh/ \#htoc-5 30 nov 18

Göteborg Frihamnen. https://www.goteborg.com/bastun-i-frihamnen/

Göteborg Valhalla. https://gotevent.se/arenor/valhallabadet/trivselregler/30 nov 18 Malmö. https://www.ribersborgskallbadhus.se/

Uddevalla. https://www.uddevalla.se/uppleva-och-gora/idrott-motion-och-friluftsliv/simhallar.badhus/trivselregler-.html 30 nov 18

Mikela Lundahl Hero is Senior Lecturer at School of Global Studies, at the University of Gothenburg with a PhD in the History of Ideas (2005) from the same institution. Her areas of research are postcolonial and queer feminist studies. Although her research has covered a broad range of topics, she returns to a number of central concepts which represent her primary intellectual interests, the most important being power and how it operates through categorisations such as race, gender, sexuality, class, identity and culture. Concepts as queer, gender, whiteness and postcolonial theory have been critical to her intellectual development. Since her scholarly training is in intellectual history, the study of texts tends to play an important part in her projects, as well as history and historiography, but more and more interviews and fieldwork has become a part of her academic practice.

Open Access This chapter is licensed under the terms of the Creative Commons Attribution 4.0 International License (http://creativecommons.org/licenses/ by/4.0/), which permits use, sharing, adaptation, distribution and reproduction in any medium or format, as long as you give appropriate credit to the original author(s) and the source, provide a link to the Creative Commons licence and indicate if changes were made.

The images or other third party material in this chapter are included in the chapter's Creative Commons licence, unless indicated otherwise in a credit line to the material. If material is not included in the chapter's Creative Commons licence and your intended use is not permitted by statutory regulation or exceeds the permitted use, you will need to obtain permission directly from the copyright holder.

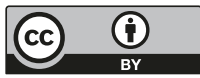

